\title{
BUSINESS DEVELOPMENT STRATEGY USING BUSINESS MODEL CANVAS APPROACH
}

\author{
Yulia $^{1}$, Novyandra Ilham Bahtera ${ }^{2}$, Evahelda $^{3}$, Laila Hayati $^{4}$, Novyandri Taufik Bahtera ${ }^{5}$ \\ ${ }^{1}$ Agribusiness Department, Bangka Belitung University \\ Email : yuliaubb@gmail.com \\ ${ }^{2}$ Agribusiness Department, Bangka Belitung University \\ Email : novyandra.ib@gmail.com \\ ${ }^{3}$ Agribusiness Department, Bangka Belitung University \\ Email : evaheldaubb@gmail.com \\ ${ }^{4}$ Sociology Department, Bangka Belitung University \\ Email : hayatilaila6@gmail.com \\ ${ }^{5}$ Business Department, Airlangga University \\ Email :novyandritb@gmail.com
}

\begin{abstract}
ABSTRAK
Dalam pengembangan suatu usaha perlu dilakukan suatu model bisnis yang dikenal dengan Business Model Canvas. Dalam model bisnis ini perusahaan bercerita tentang kondisi internal maupun eksternal perusahaan. Adapun bisnis model canvas perusahaan menampilkan model blok/elemen bisnis yang terdiri dari sembilan elemen. Pendekatan ini digunakan untuk menerapkan implementasi Business Model Canvas di UKM“Raja Abon Makmur Lestari” Kota Pangkalpinang. Penelitian ini bertujuan untuk mengevaluasi model bisnis produk abon menggunakan analisis Business Model Canvas. Data didapatkan dalam penelitian ini hasil wawancara dengan kuesioner terhadap pemilik, dua orang karyawan serta konsumen abon sebanyak 30 orang di kota Pangkalpinang serta hasil studi literatur pendukung. Hasil yang didapatkan dari penelitian ini adalah setiap elemen yang diidentifikasi telah dipertajam dengan menggunakan analisis SWOT. Dari analisis tersebut diketahui bahwa diperlukan perbaikan pada hampir semua elemen model bisnis dalam usaha raja abon makmur lestari. Perbaikan model bisnis raja abon makmur lestari terfokus kepada perbaikan kegiatan pemasaran. Terutama melalui media online guna meningkatkan pendapatan.
\end{abstract}

Kata Kunci: Analisis SWOT, Business Model Canvas, Strategi Pengembangan, Usaha Kecil dan Menengah

\section{ABSTRACT}

Business model canvas is known as an approach in business development and used as a business model. It describes about a condition of internal and external of organization. It also shows the business element which consists of nine elements. The approach is applied on the business model canvas in a small medium enterprise which is called as "Raja Abon Makmur Lestari" in Pangkalpinang City. The study aims to evaluate the business model of the product using business model canvas analysis. The data was collected through the interview using questionnaire towards the owner, two staffs and 30 customers in Pangkalpinang City and other related articles or documents. The study revealed that every identified element has been emphasized using SWOT analysis. It stated that it required the improvement on every single element of business model in Raja Abon Makmur Lestari. The improvement of business model of Raja Abon Makmur Lestari prioritized on the improvement of marketing activity especially throuh the online media in order to increase the income.

Keywords : Business Model Canvas, Development Strategy, Small and Medium Enterprise, SWOT Analysis

\section{INTRODUCTION}

Nowadays, Indonesian people face the new challenge from the external environment such as ASEAN Economic Community (Munandar, 2016). Small medium enterprise (SME) is the most powerful driver in the economic development. The SME's movement plays an important role in creating the growth and job opportunity (Soekartawi, 2013). It has its own flexibility and is easily adaptable with the fluctuated condition on demand and supply. Based on Kementerian Koperasi dan UKM of Republic of Indoensia that there are 57.8 million registered SMEs in Indonesia. Bangka Belitung Islands Province is one of provinces in Indonesia that is rich of 
various sectors including agriculture and industry. It indicates that the province has potential economic growth.

The Raja Abon Makmur Lestari (RAML) is one of SMEs that produces shredded which raw materials are both from vegetable and animal such as banana blossom, pineapple, bamboo shoot, jackfruit, beef, chicken egg and chicken meat. Yulia, Bahtera \& Evahelda (2019) states that the RAML's shredded has a special taste compared with other competitors' product. However, the marketing activity is prioritized out of province while less marketing activity in local area. The total production of RAML's product is considered as adequate. It can be shown from the positive rate of growth from year to year.

The RAML has run the business since 2013 but its development shows stagnancy. One of obstacles faced by the RAML is marketing activity as the characteristic of its raw material is perishable (Yulia, Pratiwi \& Astuti, 2019). Furthermore, the long distance between location of production and consumers becomes another obstacle that leads to the reducing quality of product.

The development of the visualization tools of business model has been conducted by Osterwalder and Pigneur (2012) in the form of BMC. The use of the model is able to explain the business model of company and the relationship amongst the components in the model (Kosasi, 2015). The model also supports the company to identify the value proposition of company as well as to show how to build and run the key activities and key resources in creating the value proposition and gaining the revenue streams. It also helps to understand how the supplied products and services of company can be well communicated and be distributed to consumers (Hartatik \& Baroto, 2017).

It is crucial for RAML to understand the description of the running business model to determine the appropriate competitive strategy to be implemented. Thus, the study focuses on conducting research in the form of business model canvas implementation on the business of Raja Abon Raja Makmur Lestari in Pangkalpinang City.

\section{RESEARCH METHODS}

\section{Location of Study}

The location of the study was chosen at RAML, Air Kepala Tujuh Village, Gerunggang District, Pangkalpinang City.

\section{Respondent}

The purposive sampling was applied in determining the type of respondents. It was decided based on their own field. There were two categories lie on respondents: internal and external. The internal respondents were the owner, the marketing manager and production manager whereas the external respondents were 30 consumers.

\section{Data Collection Techniques}

The data collection techniques used the observation, in-depth interview, and questionnaire. The study of literature review was also implemented in collecting the data and information to discover the phenomena and problem which required to be solved. 


\section{Data Processing and Analysis Methods}

Rainaldo et al., (2017) argued that the BMC analysis explains the idea on how organization creates, delivers and captures the owned value of the organization. The use of nine building blocks of business model canvas has been implementing by many both large and small scale companies. It is considered as understandable in simplifying the complicated activities in a particular company. It can be broken into two factors that affect the business environment: internal and external factor (Nasip, 2017).

\section{RESULTS AND DISCUSSION}

\section{The Implementation of Business Model Canvas on Raja Abon Makmur Lestari}

In identifying the elements of business model, it involves the internal stakeholders including the owner, Mrs Parminah. They are considered as having the ability and capacity in providing relevant information proven with the needed data to identify each element of business model canvas. They also have the authority in formulating the improvement of the next business model which in turns it will result the improved program to develop and maintain the existence of the company.

The identification of nine building blocks of business model canvas of Raja Abon Makmur Lestari is as follows:

\section{Customer Segments}

It is a targeted group of people or organization to be served by the company. The customer is the most vital role in a business model as it determines to what extent the revenue can be earned by company. The customer is not only the buyer who gives the direct revenue but also the user which the need should be taken care of company. Today, the RAML has various products which are:
a. shredded egg chicken
b. shredded chicken
c. shredded beef
d. shredded pineapple
e. shredded banana heart
f. shredded jackfruit
g. shredded bamboo shoot

Setyorini \& Rey (2017) states that a company should take care of customer as they are the core element in the business model. Thus, RAML has segmented customer in many aspects. The segmentation of the customer is:

a. the shredded egg chicken, shredded chicken and shredded beef target the segmentation on the children and teenager in Pangkalpinang. RAML decides to distribute and show the product in the souvenir center around Pangkalpinang; and

b. shredded pineapple, shredded banana heart, shredded jackfruit, and shredded bamboo shoot targets the workers who have sometimes less time to cook at home.

\section{Value Propositions}

The proposed value is essential to maintain the customers so that they will not move to another company's product (Rezqi \& Ghina, 2015). Horváth, Csík, Misley, Nagy, \& Verderber (2016) explain that the value propositions consist of knowledge basis, community development and professional activity that allow them to develop in knowledge sharing. RAML offers some benefits to the customers. The value propositions of the product are the good quality, delicious 
taste, high nutrient, experienced employees and affordable price. The main values offered by RAML are interesting packaging and halal logo. Besides, the right managerial implementation of RAML leads to the high demand of product. The product is packed with $0.1 \mathrm{~kg}$ as the lowest size. This creates the product to be easily stored.

\section{Channels}

Channel facilitates the company to connect the customers in offering and delivering the value propositions' product of company. RAML conducts the direct selling to customers through salesperson, website and souvenir center. The distribution channel considers as conventional because the online-based marketing has not been used frequently (Widyastuti \& Novian, 2018).

\section{Customer Relationships}

Personal assistance is type of relationship built by RAML which is based on the direct interaction to the customers. Wonodjojo \& Indriyani (2017) explain that customers are able to criticize and suggest the company to create the value added of the product. RAML maintains the relationship with customer through offering the product to the customers and creating group in social media. RAML uses the retention and motivation strategy to keep the customer being loyal with the company. Majority of customers keep on buying product in RAML is due to the good quality of product, delicious taste and excellent service.

\section{Revenue Streams}

Revenue streams are income earned by company in the form of money. (Kamila, Syarief, \& Saptono, 2018) describes that the transaction of selling the product can be measured in the form of money. The product can be sold from eight to ten kilo gram monthly. Half of product is normally ordered by the government institution while the rest half is distributed to the souvenir center.

\section{Key Resources}

Key resources show the crucial needed assets of company (Rukka, Busthanul, \& Fatonny, 2018). The main resources can be in the form of both physical and financial. The key resources of RAML are:
a. Physical Resources RAML's physical resources are building for residence of the owner and for the training venue.
b. Financial Resources
It is from the personal fund, government institution.

\section{c. Human Resources}
There are only two permanent employees who are the family labor while there is no permanent employees who are from no family labor.

\section{Key Activities}

There are some key activities of RAML that have been conducted which are:

a. Producing shredded

RAML use the raw materials of the product both from vegetables and animals. The company keeps on improving the quality of product through ensuring the consistence with delicious taste and high quality. 
b. Marketing

Marketing is one of key activities in RAML. The company usually send the products to the souvenir center and to the customers every month as well as participate with the exhibition held by government institution.

c. Innovation

The company innovates the product in terms of the packaging and taste.

The company develops the packaging to be more attractive using colorful aluminum foil. Next, the company begins to the new taste of product using bark as the main raw material of the new product: shredded bark.

\section{Key Partnerships}

The company maintains the relationship with the government institution. The partner supports the company in lending the drying machine for shredded so that the production process will be more effective.

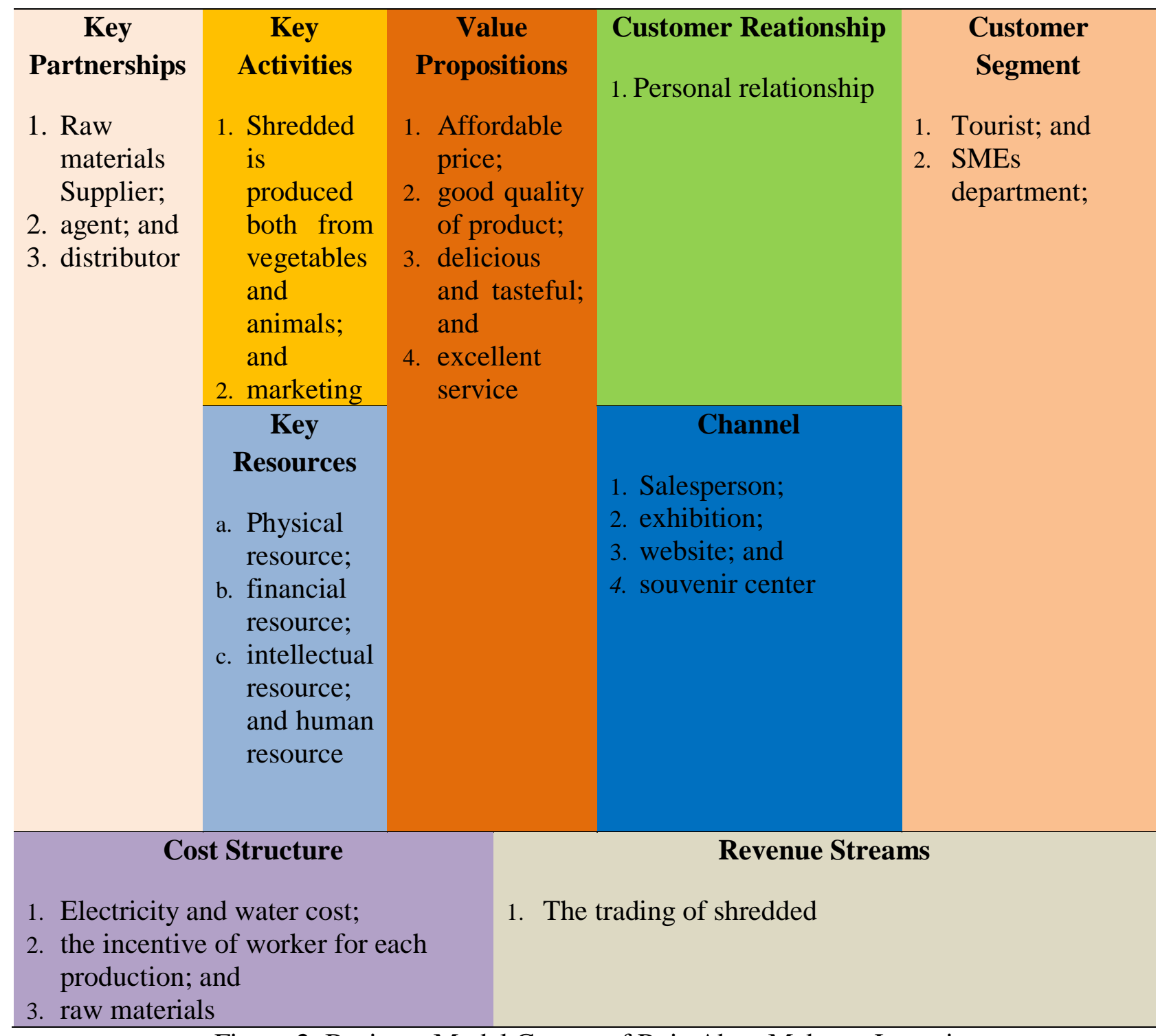

Figure 2. Business Model Canvas of Raja Abon Makmur Lestari

\section{Cost Structure}


In running company, the cost is undeniable. There will be cost in operating the business.

The cost structure depends upon the activity of key resources' management, key activities' management as well as the built partnership to support the running business model. The cost structure of producing the shredded are:

a. fixed cost including salary, electricity and water bills

b. variable cost including cost of the raw materials.

\subsection{The Prototype Design of New Business Model of Raja abon makmur lestari}

In making the prototype of new innovative business model, business model canvas can be used to plan the new business. (Andrzej Tokarski \& Maciej Tokarski, 2017). Generating idea is one of most crucial part that requires to be conducted by company. The innovative business model is needed in facilitating and supporting the change by focusing on the product and service so it can calculate the integrated product-service system approach (Amit \& Zott, 2012).

The idea of innovation can be acquire everywhere. The nine building blocks in business model can be applied as the stepping stone to improve based on the concept of business model canvas (Slávik \& Bednár, 2014). Each element can strongly affect the rest eight building blocks of business model canvas. Business innovation center can occur due to the owned source of company (key resources, key partnership and key activities), be stimulated by the offering on the creation of new value propositions, by customers (customer segments, channels and customer relationships), as well as by fund (revenue streams atau cost structures). The occurred changes are normally from the identified area through SWOT analysis by analyzing the strength, weakness, opportunity and threat of business model.

\begin{tabular}{|c|c|c|c|c|}
\hline $\mathbf{K P}$ & KA & VP & $\mathbf{C R}$ & CS \\
\hline $\begin{array}{l}\text { Raw material } \\
\text { supplier }\end{array}$ & The & $\begin{array}{l}\text { Affordable } \\
\text { nrice }\end{array}$ & Personal relationshop & Souvenir center \\
\hline $\begin{array}{l}\text { The } \\
\text { distributor } \\
\text { souvenir }\end{array}$ & $\begin{array}{l}\text { Products } \\
\text { are made } \\
\text { from } \\
\text { vegetables } \\
\text { and } \\
\text { animals }\end{array}$ & $\begin{array}{l}\text { The good } \\
\text { quality of } \\
\text { product }\end{array}$ & Catalog book & $\begin{array}{l}\text { Cooperative and } \\
\text { SMEs } \\
\text { Department }\end{array}$ \\
\hline \multirow[t]{2}{*}{$\begin{array}{l}\text { The product } \\
\text { of shredded } \\
\text { supplier }\end{array}$} & $\begin{array}{l}\text { Marketing } \\
\text { activity }\end{array}$ & $\begin{array}{l}\text { Delicious } \\
\text { taste }\end{array}$ & & $\begin{array}{l}\text { Exhibition of } \\
\text { Product }\end{array}$ \\
\hline & $\begin{array}{l}\text { Product } \\
\text { innovation }\end{array}$ & $\begin{array}{l}\text { Excellent } \\
\text { service }\end{array}$ & & \\
\hline
\end{tabular}




\begin{tabular}{lll}
\hline Institution & \multicolumn{1}{c}{$\mathbf{C}$} \\
$\begin{array}{l}\text { Physical } \\
\text { resource, } \\
\text { financial } \\
\text { resource, } \\
\text { Intellectual } \\
\text { resource } \\
\text { and human } \\
\text { resource }\end{array}$ & Tenaga penjualan \\
& Exhibition \\
& Website \\
& Souvenir center \\
\hline
\end{tabular}

\section{Cost}

RS

The electricity and water bills

The selling of product

The salary of employee each

production

The cost of purchasing the raw

materials

Figure 3. The Improvement of business model in Raja abon makmur lestari

Note:

= created

$=$ improved

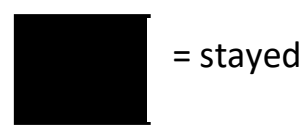

\section{Value Propositions}

In the business model alternative, the innovation begins from the change of value proposition. RAML maintains in providing the good quality of product. The strategic location also remains as the advantage of RAML. To facilitate customers in accessing the product, RAML should collaborate with souvenir center and other shops that offer the processing food. RAML should also have their own shop to facilitate the customers in purchasing the product. 


\section{Customer Segments}

RAML has two types of product: vegetables (shredded jackfruit, shredded bamboo shoot, shredded banana heart and shredded pineapple) and animals (shredded chicken, shredded beef and shredded chicken egg). Both have their own customer segmentation in Pangkalpinang City. The RAML has not maximized the available potential market. They should collaborate with specific outlets in the province to fulfill the daily market necessities on various types of shredded. While the other business unit should grab the potential customers out of province.

\section{Channels}

Word of mouth method is considered as an effective way in introducing or promoting the products to the potential customers. The use of technology should be applied to support the marketing activity. The social media and application like Facebook, Instagram, Whatspp, and Line should also be used to facilitate customers in understanding the products.

\section{Cusomer Relationships}

The strategic location of RAML will enable the customers to see, choose and purchase the needed products. The expert human resource in marketing activity will facilitate the RAML in serving the customers and reaching more customers through intensive marketing activity. The catalogue book also can be used in the website or social media to support the marketing activity. It will allow the customers in understanding the products and the promotion of RAML's products.

\section{Revenue Streams}

The revenue streams of RAML in the business model alternative can increase due to the expanding market segmentation. It goes similar when RAML collaborates with other souvenir center in Pangkalpinang City.

\section{Key Activities}

The main activity of RAML remains in producing, delivering and innovating the product of shredded. RAML has not maximized the marketing activity as they have not started using the website as marketing tool and also have no expert on digital marketing. To gain more revenue, they should utilize the digital marketing intensively in social media and their website. They also should join together with the other food processing producer such as restaurant, food shop etc.

\section{Key Resources}

RAML has land for production and plantation for the raw materials as the physical resource. They require additional physical resource such as kitchen for production that can cover more products so that they can develop the company.

\section{Key Partnerships}

Since 2013, RAML begins the company using their own cash. They are supported by government institution such as cooperative department, agriculture department, industry department and trade department. To develop and improve the physical resource, they should collaborate with the financial sector to get financial access.

\section{Cost Structure}

The change on those eight building blocks will affect the cost structure of RAML. The collaboration with the financial sector will lessen the cost structure of RAML. However, it can increase the operational cost of RAML in the future. 


\section{CONCLUSION AND SUGGESTIONS \\ Conclusion}

The identification of business model of Raja Abon Makmur Lestari is conducted through mapping the nine building blocks of business model canvas: customer segments, value propositions, channels, customer relationships, revenue streams, key activities, key resources, key partnerships, and cost structure. Each identified block has emphasized with the use of SWOT analysis. The analysis shows that it requires the improvement in almost all nine blocks of business model canvas of Raja Abon Makmur Lestari. The business model improvement of Raja Abon Makmur Lestari focuses on the marketing activity. It should be prioritized in the digital marketing to increase the revenue streams of Raja Abon Makmur Lestari.

\section{Suggestions}

The business management of Raja Abon Makmur Lestari should do the improvement on the marketing activity and the networking expansion. It should begin with the socialization to the employee so that it can be well understood and implemented to improve the existed business model. Further research should evaluate the improvement of business model to enrich the research implementation on the business model concept of Raja Abon Makmur Lestari.

\section{Acknowledgement}

The authors would like to thank the Institute of Research and Community Service (Indonesian: Lembaga Penelitian dan Pengabdian kepada Masyarakat or LPPM) of Bangka Belitung University for pleasant administration to support us financilally and morally during the conducted research.

\section{REFERENCES}

Amit, R., \& Zott, C. (2012). Creating Value Through Business Model Innovation. MIT Sloan Management Review, 53(3), 40-49

Andrzej Tokarski, Maciej Tokarski, J. W. T. (2017). The Possibility Of Using The Business Model Canvas In The Establishment Of An Operator' S Business Plan. Torun Business Review, 16(4), 17-31. https://doi.org/10.19197/tbr.v16i4.117

Hartatik, ., \& Baroto, T. (2017). Strategi Pengembangan Bisnis Dengan Metode Business Model $\begin{array}{lllll}\text { Canvas. Jurnal Teknik Industri, } & 113 .\end{array}$ https://doi.org/10.22219/jtiumm.vol18.no2.113-120

Horváth, L., Csík, O., Misley, H., Nagy, K., \& Verderber, É. (2016). The Business Model Canvas as a Tool for Assessing Curriculum Implementation Effectiveness in a Hungarian Private Secondary. Some Issues in Pedagogy and Methodology, 141-152. https://doi.org/10.18427/iri-2016-0075

Kamila, R., Syarief, R., \& Saptono, I. T. (2018). Analisis Pengembangan Bisnis Madu Pada Cv Ath-Thoifah Dengan Pendekatan Business Model Canvas. Jurnal Agribisnis Indonesia, 5(2), 173. https://doi.org/10.29244/jai.2017.5.2.173-184

Kosasi, V. M. (2015). Analisis Dan Evaluasi Model Bisnis Pada Pantai Seafood Restaurant Dengan Pendekatan Business Model Canvas. Agora, 3(1), 314-323

Munandar, A. (2016). the Strategy Development and Competitive Advantages of Micro Small Medium Entreprise Business Institution Toward Regional Development. AdBispreneur, 1(2), 103-112. https://doi.org/10.24198/adbispreneur.v1i2.10233

Nasip, I. (2017). Model Bisnis Kanvas : Alat Untuk Mengidentifikasi Peluang Bisnis Baru bagi Pengusaha UKM Indonesia. The First National Conference on Business and Entrepreneurship (pp. 205-219). Surabaya: Universitas Ciputra 
Osterwalder, A. \& Pigneur, Y., 2012. Business Model Generation. Jakarta : PT. Elex Media Komputindo

Purnawati, N. W., \& Setyohadi, D. B. (2017). The Analysis of Implementation Business Model Canvas At The E-Marketplace Dipeta Company. Scientific Journal of Informatics, 4(2), 125-133 https://doi.org/10.15294/sji.v4i2.9945

Rainaldo, M., Wibawa, B. M., \& Rahmawati, Y. (2017). Analisis Business Model Canvas Pada Operator Jasa Online Ride-Sharing (Studi Kasus Uber di Indonesia). Jurnal Sains Dan Seni ITS, 6(2), 235-239. https://doi.org/10.12962/j23373520.v6i2.25277

Rezqi, M. G., \& Ghina, A. (2015). Analisis Model Bisnis Usaha Mikro, Kecil, dan Menengah (UMKM) Di Bidang Sepatu Dengan Menggunakan Pendekatan Business Model Canvas Studi Kasus : UMKM “GZL” dan UMKM “ASJ” Di Kota Bandung Pada Tahun 2014. Journal of Chemical Information and Modeling, 2(1), 38-46. Retrieved from https://openlibrary.telkomuniversity.ac.id/home/epublication/id/32.html

Rukka, R. M., Busthanul, N., \& Fatonny, N. (2018). Strategi Pengembangan Bisnis Keripik Bayam (Amaranthus Hybridus) Dengan Pendekatan Business Model Kanvas: Studi Kasus Pada CV. Oag Di Kota Makassar, Sulawesi Selatan,. Jurnal Sosial Ekonomi Pertanian, 14(1), 41-54.

Setyorini, R., \& Rey, R. O. (2017). Analisis Model Bisnis pada Eighteen Nineteen Laundry dengan Pendekatan Business Model Canvas. Journal of Secretary and Business Administration, 1(1), 70. https://doi.org/10.31104/jsab.v1i1.2

Siregar, Z. H., \& Fitria, S. E. (2016). Analisis Model Bisnis Dengan Menggunakan Pendekatan Business Model Canvas Terhadap Usaha Mikro Agribisnis Keramat Bey Berry Ciwidey. EProceedings of Management, 3(1), 222-227. Retrieved from http://libraryeproceeding.telkomuniversity.ac.id/index.php/management/article/view/284 9

Soekartawi. 2013. Agribisnis (Teori dan Aplikasinya). Jakarta. Raja Grafindo Persada

Tim PPM Manajemen, 2012. Business Model Canvas : Penerapan di Indonesia. Jakarta: PPM.

Slávik, Š., \& Bednár, R. (2014). Analysis of Business Models. Journal of Competitiveness, 6(4), 19-40. https://doi.org/10.7441/joc.2014.04.02

Widyastuti, P., \& Novian, M. H. (2018). Pengembangan Usaha Tanaman Hias dengan Pendekatan Business Model Canvas (Studi pada Sentra Tanaman Hias di Jakarta Utara). In Conference on Management and Behavioral Studies (pp. 192-204). Jakarta: Universitas Tarumanagara.

Wonodjojo, C. D., \& Indriyani, R. (2017). Analisis Pengembangan Bisnis Dengan Pendekatan Business Model Canvas Pada Ud . Moga Jaya Surabaya. AGORA, 5(3)

Yulia, Pratiwi, F. D., \& Astuti, R. P. (2019). The Strategic Architecture to Facilitate Small and Medium Enterprise Growth " Raja Abon Makmur Lestari ” Pangkal Pinang City. In (Universitas Diponegoro) Hadiyanto, (Universitas Diponegoro) Budiyono, \& (Universitas Bangka Belitung) Ibrahim (Eds.), International Conference on Maritime and Archipelago (Vol. 167, pp. 281-288). Pangkalpinag: Atlantis Press. Retrieved from https://www.atlantis-press.com/proceedings/icoma-18/125917254

Yulia, Y., Bahtera, N. I., \& Evahelda, E. (2019). SWOT Application in Marketing Strategy for Chicken Egg Shredded in UKM "Raja Abon Makmur Lestari" in Pangkalpinang City. International Journal of Advances in Social and Economics, 1(2), 73. https://doi.org/10.33122/ijase.v1i2.43 